This is the version of a forthcoming article accepted for publication in Historical Materialism published by Brill: http://booksandjournals.brillonline.com/content/journals/1569206x

Accepted version downloaded from SOAS Research Online: https://eprints.soas.ac.uk/24790/

\title{
Limits of the Universal: The Promises and Pitfalls of \\ Postcolonial Theory and Its Critique*
}

\author{
Alexander Anievas \\ Department of Political Science, University of Connecticut \\ alexander.anievas@uconn.edu
}

Kerem Nişancıoğlu

Department of Politics and International Studies, SOAS, University of London

kn18@soas.ac.uk

\section{Abstract}

This article seeks to reassess the potential merits and weaknesses of the Subaltern Studies project through the prism of Vivek Chibber's

\footnotetext{
* We would like to thank Banu Bargu, Luke Cooper, Rob Knox, Kamran Matin, Nivi Manchanda and three anonymous reviewers for their very helpful comments on various drafts of this article. The usual disclaimers apply.
} 
much-publicised and controversial book Postcolonial Theory and the Specter of Capital. By critically examining Chibber's work, the article aims to better pinpoint exactly what is 'right' and 'wrong' with the Subaltern Studies project, while drawing out some productive points of engagement between Marxism and postcolonial theory more generally. In particular, we argue that an understanding of the origins of capitalist modernity remains a relatively unexplored omission within postcolonial thought that problematises their broader project of 'provincialising Europe'. Against this backdrop, the article explores the affinities between Leon Trotsky's notion of uneven and combined development and postcolonialism, demonstrating how the former can provide a theoretical solution to the problem of Eurocentrism that the Subaltern Studies project correctly identifies but inadequately conceptualises.

\section{Keywords}

postcolonialism - Marxism - Subaltern Studies - Eurocentrism origins of capitalism - uneven and combined development 
Vivek Chibber's Postcolonial Theory and the Specter of Capital ${ }^{1}$ has generated an unusual amount of attention for an academic work particularly so for a text dealing with a number of complex and sometimes arcane theoretical issues. ${ }^{2}$ Chibber's critique of Subaltern Studies - and postcolonialism more generally by his reasoning - has provoked a polarised and lively response from scholars working within a variety of disciplines (Political Economy, Cultural Studies, Sociology, International Relations, etc.) and different theoretical and political traditions. To some extent, this is not surprising. Postcolonial Theory is an intentionally provocative and polemical text which was bound to incite passionate responses, particularly from the subjects of Chibber's critique and their most ardent detractors. And so it has. Those working within the Subaltern and postcolonial traditions - the two not being entirely identical ${ }^{3}$ - have responded in kind, from questioning the validity of Chibber's interpretations of their and other colleagues' work, ${ }^{4}$ to challenging the extent to which his critique of Subaltern Studies applies to postcolonial theory more generally, ${ }^{5}$ to crossexamining Chibber's own self-proclaimed Marxist credentials. $^{6}$ In

\footnotetext{
${ }^{1}$ Chibber 2013.

2 See, inter alia, Vanaik 2013; Chatterjee 2013; Levien 2013; Watson 2013; Murphet 2014; Brennan 2014 [inserted into bibliography - MC]; Jani 2014; Ahmed 2014; Spivak 2014; Journal of WorldSystems Research 2014; Nilsen 2015; Lazarus 2016.

${ }^{3}$ For an illuminating discussion of the distinct intellectual lineages of postcolonialism and Subaltern Studies, see Lazarus 2016, pp. 93-5; Parry 2017. [no such entry in bibliography - MC]

${ }^{4}$ Cf. Chatterjee 2013; Seth 2014; Murphet 2014; Roy 2015.

${ }^{5}$ See especially Spivak 2014.

${ }^{6}$ Cf. Murphet 2014.
} 
contrast, a number of Marxist commentaries on the book have hailed

it as a blistering and systematic demolition of postcolonial theory's pseudo-radical, anti-universalist strand of postmodernist-influenced obscurantism. ${ }^{7}$ The internal Enemy Other has been identified and slain.

Of course, Chibber's book is neither the first Marxist critique of postcolonialism nor the first critique of postcolonialism's historical and sociological analyses. ${ }^{8}$ However, it has been the most widely publicised and debated and, for this reason alone, merits scrutiny. Postcolonial Theory has also been successful in sparking a renewed debate on the relationship between Marxism and postcolonial theory, though perhaps not the one Chibber had hoped for. ${ }^{9}$ As Timothy Brennan points out, many reviewers of Postcolonial Theory have seen it as a 'showdown between Marxism and postcolonial theory', though

\footnotetext{
${ }^{7}$ Ahmed 2014; Schwartz 2014.

8 Unfortunately, Chibber assigns many extant Marxist criticisms of postcolonial theory to the 'literary and cultural fronts' (Chibber 2013, pp. 4-5, n. 7) without acknowledging the much broader scope of critique represented by these works and others. As we shall see, a more direct engagement with this broader literature of Marxist works on postcolonialism would have likely strengthened Chibber's analysis and perhaps corrected some of the more problematic aspects of his critique (cf. Lazarus 2016). As Neil Lazarus notes in regard to Chibber's consignment of such works (including his own) to solely cultural and literary issues, this enables 'Chibber to claim that his study is the first to set out "to examine the framework that postcolonial studies has generated for historical analysis and, in particular, the analysis of what once was called Third Worldism"' (Lazarus 2016, p. 91). The problem for Chibber, as Lazarus points out, is that many of these works do critique postcolonialism's historical analyses. And given Chibber's non-engagement with this wider body of literature, he 'ends up having to reinvent the wheel on quite a few occasions' (Lazarus 2016, p. 92). For some particularly notable Marxist critiques in this regard, see the collection of essays in Bartolovich and Lazarus (eds.) 2002, especially chapters by Lazarus, Nimtz, and San Juan; Ahmad 1992; Larsen 2001; Kaiwar 2004 and 2014; Parry 2004 [no such reference in bibliography MC]; Lazarus and Varma 2008; Matin 2013.

${ }^{9}$ Cf. Brennan 2014; Murphet 2014; Nilsen 2015; Lazarus 2016; Parry 2017 [no such reference in bibliography - MC]. For useful overviews of postcolonialism's relationship to the Marxist tradition, see Chakrabarty 2005; Young 2001; and Lazarus and Varma 2008.
} 
Brennan suggests that the more interesting divide - unrecognised by either Chibber or most of his interlocutors - is one within Marxism itself: 'the internal bifurcation of humanist and social-scientific interpretations of Marxism'. ${ }^{10}$

This is indeed an interesting question that sheds a rather different light on Chibber's assessment of postcolonial theory's 'rejection' of Marxism, ${ }^{11}$ his dismissal of Robert Young's tracing of postcolonialism back to the anti-colonial Marxist tradition as 'spectacularly mistaken', ${ }^{12}$ and his characterisation of the original Subaltern Studies project as an 'amalgam of liberal and Marxist elements'; a Marxism, yes, but 'one of a particular kind' that 'would be scarcely recognized by many contemporary Marxists'. ${ }^{13}$ Perhaps. But then much the same could be said of Chibber's own favoured brand of Marxism: a peculiar combination of liberal and Marxist elements drawing upon the Rational Choice Marxism of Jon Elster and Erik Olin Wright and the Political Marxism of Robert Brenner and Ellen Wood, dosed with a mix of Rawlsian social-contract theory (to which Chibber 'proudly' adheres) ${ }^{14}$ and the work of modernisation theorist Amartya

\footnotetext{
${ }^{10}$ Brennan 2014, p. 82.

11 Chibber 2013, p. 2.

12 Chibber 2013, p. 290.

${ }^{13}$ Chibber 2013, p. 10; emphasis in original.

${ }^{14}$ See Chibber's comments during a debate on 'Marxism and the Legacy of Subaltern Studies' held at the Historical Materialism New York 2013 Conference, which can be found at: $<$ https://www. youtube.com/watch?v=xbM8HJrxSJ4 >.
} 
Sen. This is a Marxism, we agree, but also a Marxism of 'a particular kind', which at least some contemporary Marxists would not recognise. ${ }^{15}$ The Marxist historian Utathya Chattopadhyaya, for example, has criticised Chibber for 'situating Marx and Rawls in the same genealogy where liberalism and Marxism appear wholly compatible under an Enlightenment umbrella', which 'is indicative of how liberal rights-based leftism has pervaded the space of rigorous Marxist critique', ${ }^{16}$ while others have chastised the work as being too entrenched in rational choice methodological assumptions and thus 'undialectical'. ${ }^{17}$ There is some truth to these criticisms. ${ }^{18}$ However, as other reviewers have discussed these subjects at length elsewhere, we will instead focus on the substantive content of Chibber's main criticisms of Subaltern Studies, which in part connects with some of the interpretive issues raised by Partha Chatterjee and others ${ }^{19}$ but which have remained inadequately assessed.

\footnotetext{
15 Interestingly, the same historical socio-political conjuncture - the waning of the labour movement in the wake of the frontal assault by neoliberalism in the late 1970s and 1980s and the concomitant retreat of radicals to the academy - that produced the ostensibly disfigured form of Marxism practised by the Subalternists also produced the Analytical and Political-Marxist traditions that Chibber so heavily draws upon.

${ }^{16}$ Chattopadhyaya 2014. [Chattopadhyaya 2014? - MC]

17 Levien 2013; Murphet 2013.

18 Whether or not Chibber's analysis is properly 'Marxist enough' is beside the point and not a particularly useful criterion for adjudicating the strengths and weaknesses of his arguments. Criticisms of Chibber's particular methodology are, however, germane to such discussions and, in this respect, the rational choice assumptions of his analysis merit scrutiny (see Levien 2013; Murphet 2013). Most problematic in this regard is Chibber's adherence to Rawlsian social-contract theory and a strong liberal-Enlightenment conception of universalism, both of which are Eurocentric. Situating Marx within this Enlightenment tradition is also somewhat problematic as he neither shared their form of method nor universalism, which is at the crux of many of the issues raised by Chibber's critics.

19 Chatterjee 2013; Levien 2013; Seth 2014.
} 
One might nonetheless question the rationale for offering yet another critique of a work that has already received so much scrutiny. To be clear, our aim is not to provide a systematic critique of Postcolonial Theory, but rather to use Chibber's Marxist-inspired critique of the Subaltern project as a foil to reassess the strengths and weakness of postcolonial theory, and Marxist engagements with postcolonialism more generally. We find this particularly useful for two reasons. First, given the attention Chibber's work has garnered it will likely be a launching-pad for many subsequent discussions and debates on the potentials and pitfalls of postcolonialism, particularly within Marxist circles. For this reason, it is important for our discussion to assess the merits of Chibber's critique and, in particular, his interpretation of the Subaltern Studies works he engages (particularly, for our purposes here, those of Dipesh Chakrabarty and Ranjit Guha).

Our focus on Chibber's work in this regard is, then, not due to the fact it represents the only systematic or even best example of an avowedly Marxist critique of postcolonial theory, but instead because it will likely prove a highly influential - and contested - one which, as we shall demonstrate, reveals as much as it obscures in critiquing the Subaltern project. Second, by critically examining Chibber's work, we aim to better pinpoint exactly what is 'right' and 'wrong' with postcolonial studies. Specifically, an understanding of the origins of 
capitalist modernity remains a relatively unexplored omission within postcolonial thought that, we argue, problematises the broader postcolonial project of 'provincialising Europe'. We consider this especially apposite since Chibber's own analysis focuses on a number of substantive historical sociological claims of the Subalternists and, in particular, Guha's account of the early bourgeois revolutions in Europe. Against this backdrop, we then explore the affinities between Leon Trotsky's notion of uneven and combined development and Postcolonialism, ${ }^{20}$ demonstrating how the former can provide a theoretical solution to the problem of Eurocentrism and understanding sociohistorical difference that the Subalternists identify but inadequately conceptualise.

The themes raised by Chibber's critique of the Subaltern project and our analysis of it are crucial to broader debates on the standing (and potential limits) of the universal in social theory, the logic and history of capitalist development and how it encounters societal multiplicity and difference, and therefore also our conceptions of the making of the modern world itself. Here it is worth highlighting one central point of critique offered by Chibber that we agree with and

\footnotetext{
20 It is worth noting that postcolonialism is a highly diverse tradition of thought, which is not reducible to the work of any particular author or approach. In this article, we focus primarily on Subaltern Studies as one (hugely important, itself diverse) approach operating within this much wider tradition. We do so in part in order to tackle the criticisms offered by Chibber, who focuses exclusively on Subaltern Studies.
} 
believe is highly significant. Chibber's defence of the utility - indeed, necessity - of Marxist theories and concepts is, of course, one we strongly adhere to: hence our own use of Trotsky's idea of uneven and combined development. Where we nonetheless depart from Chibber is over the extent to which these concepts and theories can be applied to particular spaces and histories in an unmediated fashion; that is to say, we differ on the extent to which they need to be 'translated' and reconfigured to fit the socio-historical specificities of different locales. ${ }^{21}$ The uneven and interactive character of development across time and space demands the kind of 'slightly stretched' Marxism that Franz Fanon called for ${ }^{22}$ in understanding the colonial experience and which we have sought to further develop in explaining the rise of capitalism itself. ${ }^{23}$ The point is that Marxists should not shy away from the postcolonial critique of Eurocentrism, but rather directly engage with it as the Marxist tradition offers invaluable resources for breaking out of the Eurocentric cage.

Before engaging with these issues, we must first address three fundamental questions: what are Chibber's central criticisms of

\footnotetext{
${ }^{21}$ For a discussion of this point vis-à-vis the question of defining capitalism, see Anievas and Nişancıoğlu 2016.

22 Fanon 1963, p. 40.

${ }^{23}$ Anievas and Nişancıoğlu 2015.
} 
postcolonial theory? What constitutes postcolonialism as such? And what are its main theoretical aims and objects of analysis?

\section{The Problematic of Sociohistorical Difference}

'Postcolonial Theory and the Specter of Capital': Argument Explained

Chibber's critique of postcolonial theory rests on three central claims.

First, that Ranjit Guha's argument that capitalism failed to 'universalize once it left European shores' ${ }^{\prime 24}$ and the Subalternists' denial of capital's real universalising tendency ${ }^{25}$ are mistaken. Chibber claims that Guha (and the Subaltern project more generally) views capital's universalising tendency as encompassing 'two distinct elements': (1) the "'self-expansion of capital"', and; (2) the cultural and political transformations wrought in its wake. ${ }^{26}$ The problem for the Subalternists is that they conflate these two distinct elements, leading them to argue that if the latter socio-cultural transformation is absent within a particular society then capital's universalising tendency must be judged a failure. However, the Subalternists' rejection of capital's

\footnotetext{
${ }^{24}$ Chibber 2014a, p. 312.

25 Chibber 2013, p. 100.

26 Chibber 2013, p. 110.
} 
real universalising tendency is, Chibber argues, based upon a misunderstanding of what capitalism is in fact universalising: a particular reproductive strategy based on market-dependence..$^{27}$ Once we correct this misunderstanding, then it becomes clear that capitalism has indeed universalised.

Flowing from this line of critique emerges Chibber's second key claim: that the developmental divide between 'West' and 'East' posited by Subalternists - in terms of the character of their respective national bourgeoisie, power relations, and the 'political psychology' motivating agents - is false. Chibber explicates these arguments in the historical and sociological chapters of the book on the early bourgeois revolutions (Chapters 2-4), power (Chapters 5-6), and the driving forces of subaltern resistance (Chapters 7-8). Third, given the 'essential convergence of capitalist strategies West and East', Chibber claims that these two forms of society must be considered 'variants of the same species' and therefore may be understood and explained by theories emanating from the European experience. ${ }^{28}$ As such, Chibber argues for the applicability - indeed necessity - of Western-based (Enlightenment) universal categories and theories to capture the basic 
structural developmental trajectories of societies both in the 'West' and 'East'.

We will examine each of these claims below. Before doing so, we must first explicate what postcolonialism is and is not, and what are its main arguments and objects of analysis.

\section{Postcolonial Studies Engaging Capital}

Dealing with issues of historical difference and theoretical homogeneity in correcting the Eurocentric bias of social theory is at the heart of what might broadly be termed postcolonialism. Two central elements of postcolonialism are worth highlighting in this regard. Firstly, postcolonial scholars have sought to 'provincialise' Europe by decentring the Eurocentric claim that Western social forms and accompanying discourses are homogenously universal. ${ }^{29}$ Postcolonial approaches emphasise that European modernity and identity have always been constituted against - and through the subordination of a non-Western 'Other' ${ }^{30}$

In so doing, these authors stress the centrality of colonial practices as deeply embedded within the structure of European power 
and identity. ${ }^{31}$ Consequently, postcolonialism places the particularity of alternative visions of society originating in non-Western cases at the heart of its research programme. ${ }^{32}$ By 'giving a voice to the Other', postcolonialism shows how subaltern experiences have disrupted Eurocentric visions of history, thereby reasserting the significance of non-Western agency in world history. ${ }^{33}$

The second step draws on the first in order to assert the heterogeneity of all social development and its irreducibility to exclusively European forms. According to postcolonialism, history is neither universal nor homogenous, but marked by difference, hybridity and ambivalence - in short, multiplicity. As such, postcolonialism also seeks to dislodge the linearity of historical time, and reject any possibility of stadial conceptions of development. ${ }^{34}$ For the Subaltern project in particular, as Partha Chatterjee suggests, ${ }^{35}$ this has meant studying how the dynamics and processes of primitive accumulation have operated under different historical conditions. We believe these two pointers - a non-Eurocentric and multilinear history - to be the primary strengths of the postcolonial approach and where its promise for the study and critique of capitalism lies. We examine each in turn,

\footnotetext{
31 Cf. Inayatullah and Blaney 2004; Bhambra 2007.

32 Acharya 2011.

33 Bhabha 2012.

34 Cf. Bhambra 2007, especially pp. 34-55.

35 Chatterjee 2013 ('Marxism and the Legacy of Subaltern Studies').
} 
with a particular focus on Dipesh Chakrabarty's Provincializing Europe and Ranajit Guha's Dominance without Hegemony, which form two of the main targets of Chibber's critique.$^{36}$ In this way, we hope to avoid some of the pitfalls of attempting a general overview of a highly heterogeneous research programme. Nonetheless, we also consider Chakrabarty's and Guha's work to be of particular importance to the 'postcolonial phase of Subaltern Studies', ${ }^{37}$ and thus deserving of special attention.

\section{The Eurocentrism of Historicism}

Annihilating Difference through Time and Space

Postcolonialism is, first and foremost, a specific reaction against attempts in Western thought - most notably, liberalism, modernisation theory and Marxism - to subsume all sociohistorical realities under the universal rubric of capitalist modernity. These universalist accounts suffer because they tend to either misread or, worse, overlook difference. Chakrabarty calls this 'historicism' - a way of writing history

\footnotetext{
36 The other key works that Chibber examines are Partha Chatterjee's The Nation and Its Fragments (1993) and Nationalist Thought and the Colonial World (1986).

37 Kaiwar 2014, p. 28.
} 
that 'both recognizes and neutralizes difference', wherein 'differences among histories' are 'overcome by capital in the long run'. ${ }^{38}$ Historicism tends to portray capitalism 'as a force that encounters historical difference' externally, struggles with this difference, and eventually negates or, more precisely, subsumes it 'into historically diverse vehicles for the spread of its own logic'. ${ }^{39}$

Such an approach carries with it a specific kind of highly politicised prescription. By positing Europe 'as the site of the first occurrence of capitalism, modernity, or Enlightenment', nonEuropeans were assigned a place 'elsewhere'. ${ }^{40}$ Historical developments subsequently came to be judged almost exclusively against a European norm, and those histories which did not fit or comply with that norm were dismissed as 'incomplete'. Differences come to be articulated through (and thus abolished by) essentialised binaries such as 'pre-capitalism' and 'capitalism', 'modern' and 'premodern', 'archaic' and 'contemporary', 'world-empires' and 'worldsystem', and the like.

The very notion of incompleteness carries within it the sort of hierarchies that were present in colonialism (such as notions of 'barbarism', 'uncivility', 'backwardness', 'inadequacy'). Historicism

\footnotetext{
38 Chakrabarty 2008, pp. 47-8.

${ }^{39}$ Chakrabarty 2008, p. 48.

40 Chakrabarty 2008, pp. 7-8.
} 
consequently posits 'a measure of the cultural distance ... that was assumed to exist between the West and the non-West', ${ }^{41}$ and became a way of saying to non-Europeans, 'wait! not yet!' in their calls for autonomy and recognition. ${ }^{42}$ This becomes most evident when examining the 'peasant' or 'subaltern'. For example, Eric Hobsbawm's characterisation of the (Indian) peasant in history as 'pre-political' and 'archaic' is rooted in an understanding of non-European development as 'incomplete'. ${ }^{43}$ These agents are seen as a survival or remnant of pre-capitalist relations. More recent iterations of this same strategy can be found, according to Chakrabarty, in notions of 'uneven development', which ascribes 'at least an underlying structural unity (if not expressive totality) to historical process and time that makes it possible to identify certain elements in the present as "anachronistic" or "outmoded"'.44

Traces of the Non-Universal

\footnotetext{
${ }^{41}$ Chakrabarty 2008 , p. 7. Historicism is therefore heavily inscribed within the narrative of historical 'transition'. Within the transition narrative, history tends to be hung between 'the two poles of homologous sets of oppositions: despotic/constitutional, medieval/modern, feudal/ capitalist'. In colonial histories then 'this transition narrative was an unabashed celebration of the imperialists' capacity for violence and conquest' (Chakrabarty 2008, p. 32).

${ }^{42}$ Chakrabarty 2008, p. 8; see also Chatterjee 2010, pp. 296-7.

${ }^{43}$ Chakrabarty 2008, pp. 11-12.

${ }^{44}$ Chakrabarty 2008, pp. 12, 47. Gurminder Bhambra's (2011) criticism of uneven and combined development similarly questions the conceptual and theoretical emphasis on an unproblematised conception of development. For an examination of such criticisms, see Anievas and Nişancıoğlu 2015, pp. 43-63.
} 
Historicism becomes especially problematic when we consider the centrality of the peasant in the making of modernity. Peasant agency, although distinctly non-bourgeois and non-secular and historically connected to practices that existed prior to colonialism, was still unequivocally both political and modern. ${ }^{45}$ Indeed, as David Washbrook argues, the very prevalence of a 'backward' or 'traditional' stratum of society (in contrast to the 'modern') was itself a result of the construction of colonialism in South Asia. ${ }^{46}$

The act of subsuming the peasant under the rubric of the "premodern', 'pre-capitalist' or 'pre-capital' therefore reflects nothing other than the violent attempt to fit the subaltern 'into the rationalist grid of elite consciousness', in a way that makes them intelligible to colonialists and bourgeois nationalists. ${ }^{47}$ The upshot is an otherwise politically significant peasantry becoming silenced, misrepresented or marginalised by history-writing. For this reason, Chatterjee seeks to recast the historical question of non-European modernity in different terms:

Are we to explain 'retarded' capitalism simply in terms of a

\footnotetext{
${ }^{45}$ As such, the peasant is lauded within postcolonialism as the agent that subverts historicism by its very agency, by its very participation in the 'path' of history it has been denied entry to - it is the non- rather than pre-bourgeois, the non- not pre-modern (Chakrabarty 2008, pp. 10-11). 46 Washbrook 1990.

${ }^{47}$ Chatterjee 2010, p. 292.
} 
time lag, or should we treat it as an expression of the historical limits of Capital's universalising mission? To choose the latter would require us to abandon a methodological procedure designed to explain the emergence of capitalism as a universal system of generalized commodity production and to substitute in its place one that enables us to identify and explain the limits to the historical actualisation of Capital as a universal economic category. ${ }^{48}$

One of the primary concerns of postcolonialism is therefore to 'provincialise Europe' by showing 'how universalistic thought was always and already modified by particular histories'. ${ }^{49}$ To put it differently, it seeks to demonstrate that concepts and categories that purport to be universal always contain within them traces of the notuniversal.

This is evident in two respects. First, postcolonialists seek to show how seemingly 'universal' concepts of political modernity 'encounter pre-existing concepts, categories, institutions and practices through which they get translated and configured differently'. ${ }^{50}$ Second,

\footnotetext{
${ }^{48}$ Chatterjee 1983, pp. 64-5.

${ }^{49}$ Chakrabarty 2008, p. xiv.

50 Chakrabarty 2008, p. xii; interestingly, Chakrabarty implies that this is itself a universal law of history, when he suggests that if this argument is true of India, then it is true of any other place as well, including Europe'. See also Chatterjee 2010, p. 294.
} 
postcolonialists aim to demonstrate how ostensibly universal categories are in fact themselves particular and provincial, in that they were the product of a specific European experience. ${ }^{51}$ Chatterjee highlights that the supposed universalism of European social forms in fact masks a particular historical experience, which only became universal due to the specific history of capitalism:

If there is one great moment that turns the provincial thought of Europe to universal philosophy, the parochial history of Europe to universal history, it is the moment of capital capital that is global in its territorial reach and universal in its conceptual domain. It is the narrative of capital that can turn the violence of mercantile trade, war, genocide, conquest and colonialism into a story of universal progress, development, modernization, and freedom. ${ }^{52}$

The universality of capital thereby allows for the writing of a universal history in a way previously unimaginable. For the Subalternists, this universality does not, however, imply an emptying-out or 
homogenisation of the concrete particularities of any given society, but can in fact work to reconstitute and produce such societal differences.

The Internal Limits to Capital's Universalising Tendency

It should be clear from the outset, then, that the likes of Chatterjee, Chakrabarty and Guha do not deny capital's universalising tendency. ${ }^{53}$ Indeed, nowhere do each of the Subaltern Studies scholars castigated by Chibber deny that capital demonstrates a real tendency toward universalisation. Rather, their claim is an altogether different one: that capital's universalising tendency is necessarily limited, always and everywhere partial - all points made by Chibber himself.

For example, Chakrabarty highlights the "'resistance to capital"' that Marx speaks of as 'something internal to capital itself'. Hence, 'the self-reproduction of capital', as Chakrabarty notes, going on to invoke another quote from Marx,

53 Chibber claims, for example, that his historical-sociological analysis proves that the universalization of capital is real, pace the claims of the Subalternist collectivity', while elsewhere noting that they are 'wrong in identifying what is actually universalized' by capital (Chibber 2013, pp. 285,100 ). Chibber ultimately overstates his case by arguing that postcolonialists seek to 'defend the specificity of the East' by 'denying the applicability of Western theory's universalizing categories' and 'denying that capital successfully universalizes' (Chibber 2013, p. 212). As we shall see, none of these charges are accurate. 
'moves in contradictions which are constantly overcome but just as constantly posited'. Just because, he [Marx] adds, capital gets ideally beyond every limit posed to it by 'national barriers and prejudices', 'it does not by any means follow that it has really overcome it'. ${ }^{54}$

This passage taken from Marx's Grundrisse is also quoted in full by Guha, after which he writes: 'Nothing could be more explicit and indeed more devastating than this critique of the universalist pretensions of capital'. ${ }^{55}$ This is important given that Guha is here explicitly claiming that while capital's universalising drive is a real historical tendency it is also one met by certain counter-tendencies or limitations inhering in capital's own logic of process.

Moreover, following Marx again, Guha views this contradictory unity of universalising and counter-universalising tendencies as operating within both 'the East' and 'West' (specifically Europe). For Marx, Guha explains:

the discrepancy between the universalizing tendency of capital as an ideal and the frustration of that tendency in 
reality was, for him, a measure of the contradictions of Western bourgeois societies of his time and the differences which gave each of them its specificity. ${ }^{56}$

In contrast to Chibber's critique, capital's 'universalising mission' was limited in both the Global South and North for Marx (as Guha renarrates him) - the latter being exemplified by the 'incomplete' character of the 'bourgeois revolutions' of Marx's own time as demonstrated in Germany and elsewhere. Thus, the 'structural fault in the historic project of the bourgeoisie' Guha highlights ${ }^{57}$ was not simply between, as Chibber asserts, 'the Indian bourgeoisie and its predecessors' in Europe. ${ }^{58}$ It was instead a broader spatio-temporal fault-line traversing the entire world: one between the 'early' bourgeois revolutions in England and France, on the one hand, and the later bourgeois revolutions running east of the Elbe in Europe as well as those beyond Europe as with India, on the other. This understanding of the differentiated spatio-temporal ordering of the bourgeois revolutions, whereby the further they travelled in space and time from capitalism's inception the more differences accumulated, ${ }^{59}$ is, we

\footnotetext{
56 Guha 1997, p. 16; emphasis ours.

57 Guha 1997, p. 5.

58 Chibber 2013, p. 39

59 Anderson 1992, p. 116.
} 
would argue, more consistent with the historical record than Chibber's own account of the English and French revolutions that denies their anti-feudal character whilst misconstruing the role the bourgeoisie played in them. ${ }^{60}$

\section{The Violence of Abstraction}

The Liminality of the Universal

The postcolonial project of provincialising Europe is therefore not about rejecting the universality of capitalist modernity out of hand; or, in Chakrabarty's terms, it is not a project of cultural relativism. ${ }^{61}$ These authors accept that capitalism has a universal reach, only too brutally demonstrated by the histories of colonialism and imperialism. What they reject is using this universal conception of capital as the 'sole' or 'sovereign' author of historical processes, in a way that turns all other particular histories into differentiated expressions of European

\footnotetext{
${ }^{60}$ Cf. Chibber 2013, pp. 54-79. Our alternative understanding of the English and French capitalist revolutions is explicated at length in Anievas and Nişancıoğlu 2015, Chapter 6. An important point Chibber is correct in stressing is that neither the English nor the French bourgeoisie aimed to create liberal-democratic orders. The construction of such orders was instead the product of the subaltern struggles emanating from workers and peasants in the course of the revolutionary process. Why this point requires an entire chapter recounting the history of the English and French revolutions is unclear, particularly in light of the criticisms of Chibber's misreading of Guha's argument (see below).

${ }^{61}$ Chakrabarty 2008, p. 43.
} 
history. ${ }^{62}$ The aim is to 'displace a hyperreal Europe from the center toward which all historical imagination currently gravitates' ${ }^{\prime 63}$ by (re)writing these non-universal, particular and local histories 'back in'. From this perspective, postcolonial scholars seek to highlight the inherent liminality of universal categories in fully capturing the broad range of sociohistorical processes operating in the 'extra-European' and European world. This in turn demands an examination of the myriad hybrid sociopolitical forms produced by capital's universalisation and thus interaction and contestation with "pre-existing concepts, categories, institutions and practices' ${ }^{\prime 6}$ in both European and non-European locales.

This aim of identifying parts of social life not subsumed by the universality of capital leads Chakrabarty to a highly stimulating reading of Marx's later writings. ${ }^{65}$ In particular, Chakrabarty singles out Marx's category of 'abstract labour' as the concept that captures the homogenous and homogenising tendency in capital. According to Marx, the practice, act, or performance of abstraction becomes apparent in workplace discipline, wherein the 'life' or 'living labour' of the worker is abstracted-from and subsumed by 'dead labour' - the

\footnotetext{
62 Taylor 2010.

63 Chakrabarty 2008, p. 45.

64 Chakrabarty 2008, p. xii.

65 Chakrabarty 2008, pp. 59-68.
} 
machine. Such an abstraction enables the homogenisation and thus equalisation of various, particular or concrete instances of labour to become the measure of wealth under capitalism. It is also through this abstraction that wealth itself is created. In order to extend relative surplus labour, labour-saving technologies are introduced, thus reducing to a minimum the amount of living labour necessary for production. In this respect, the abstraction of labour also acts as the mechanism through which labour is 'emancipated'. ${ }^{66}$ This tendency to simultaneously exploit and emancipate labour thus constitutes what Marx calls the 'moving contradiction' of capital. ${ }^{67}$

For Chakrabarty, the significance of these claims about abstract labour is that inscribed in the very universality of abstract labour is its opposite - real labour. This denotes the specific acts of labour that make abstract labour a possibility, but also points to the element of 'life' or 'living' for the worker, and the attempt of the worker to reappropriate their 'life', as the basis of resistance against capital. Thus, given in the very universality of abstract labour is a particularity - real labour - that remains never quite conquered by capital. It is on the basis of this distinction that Chakrabarty introduces the concepts of 'History 1' and 'History 2'.

\footnotetext{
66 Marx 1973, p. 701.

67 Marx 1973, p. 706.
} 
History 1 refers to that past presupposed by capital, 'a past posited by capital itself as its precondition' and 'its invariable result'. ${ }^{68}$ Although Chakrabarty leaves this largely unspecified, it is clear from his preceding discussion that what he has in mind is abstract labour. In contrast, History 2 refers to those histories that are encountered by capital 'not as antecedents' established by itself, nor 'as forms of its own life-process'. ${ }^{69}$ History $2 \mathrm{~s}$ are not 'outside' of capital or History 1. Instead, they exist 'in proximate relationship to it', ${ }^{70}$ whilst potentially 'interrupt[ing] and punctuat[ing] the run of capital's own logic'. ${ }^{71}$

Although Chakrabarty is clear in his definition, he is somewhat elusive when it comes to the exact content of History 2. Nonetheless, with his discussion of abstract labour in mind, he does appear to be talking about those elements involved in the reproduction of labourpower that are not subsumed by abstract labour itself. Others, most notably feminist authors, have theorised some of these aspects of History 2 as the 'reproductive' or 'unwaged' sphere. ${ }^{72}$ History 2 also draws affinities with biopolitics, those elements of politics and society found 'in the person's bodily habits, in unselfconscious collective practices, in his or her reflexes about what it means to relate to objects

\footnotetext{
${ }^{68}$ Chakrabarty 2008, p. 63.

${ }^{69}$ Chakrabarty 2008, p. 63; Marx 1973, pp. 105-6.

70 Chakrabarty 2008, p. 66.

71 Chakrabarty 2008, p. 64.

72 See e.g. Delphy and Leonard 1984; Federici 2012.
} 
in the world as a human being and together with other human beings in his given environment'. ${ }^{73}$ History 2 s can additionally involve aspects that are in fact antithetical or generate resistance to capital's own 'lifeprocess' - that is, capital's logic of self-reproduction - which might include particular cultural formations, customs and ideologies. A concrete example of this element would be the pre-existing cultures of workers in the Calcutta Jute mills that Chakrabarty examined in a previous study. ${ }^{74}$ Hence, History 2 s may well include non-capitalist, pre-capitalist or local social relations and processes. However, the concept is not exhausted by these, and can refer to universal and global categories, social relations and processes.

Indeed, following Marx, two of the examples Chakrabarty gives of History $2 s$ include commodities and money - two universal categories central to the functioning of capitalism. ${ }^{75}$ Hence, Chibber's criticism that Chakrabarty uses History 2 to refer to merely local ('Eastern') manifestations of abstract and universal (or 'Western')

\footnotetext{
${ }^{73}$ Chakrabarty 2008, p. 66.

${ }^{74}$ Chakrabarty 2000.

75 '[Capital] originally finds the commodity already in existence, but not as its own product, and likewise finds money circulation, but not as an element in its own reproduction... But both of them must be destroyed as independent forms and subordinated to industrial capital' (Marx quoted in Chakrabarty 2008, p. 64). Chakrabarty therefore notes (Chakrabarty 2008, p. 64) that the heterogeneity Marx reads into the history of money and commodity shows that the relations that do not contribute to the reproduction of the logic of capital can be intimately intertwined with the relations that do'. Put in different terms, while History $2 \mathrm{~s}$ may lie outside capital's logic of selfreproduction, through their relational position within the wider totality of capitalist society they can nonetheless function to reproduce it.
} 
processes $^{76}$ is inaccurate. History 1 is not simply 'an abstract definition', the 'universal' or 'the West'; nor is History 2 by contrast seen as a concrete manifestation, local, and/or Eastern, ${ }^{77}$ as Chibber reads it - notably, Chakrabarty himself nowhere defines History 1 and History 2 as any of these. ${ }^{78}$

Rather, History 1 functions as an analytical history. It abstracts from specific instances in order to 'make all places [histories] exchangeable [comparable] with one another'. ${ }^{79}$ But, moreover, the conception of History 1 as a set of abstract categories - abstract labour, exchange-value, etc. - designate what Alfred Sohn-Rethel called 'real abstractions'. ${ }^{80}$ These are more than just 'abstract descriptions' or 'abstract delineations' - that is, concepts - but relations and processes that affect the functioning of capitalism as a mode of production. The very act of abstracting - as both Marx and Chakrabarty argue - from the individual concrete labour of each

\footnotetext{
${ }^{76}$ So when Chibber castigates Chakrabarty for not comprehending that 'no practice ever conforms in every detail to its abstract conception. It is not an insight, therefore, to declare that this or that social fact has elements in it that are not present in its abstract delineation' (Chibber 2013, p. 227), it is clear that this is down to a fundamental misreading of the meaning of the 'abstract' in both Marx and Chakrabarty.

77 Chibber 2013, pp. 235, 238.

${ }^{78}$ As David Blaney and Naeem Inayatullah put the matter (Blaney and Inayatullah 2010, pp. 1678), Chakrabarty's reading of Marx's narrative in terms of History 1 and 2 'allows two historical stories: one comprising elements that are the logical/historical preconditions of capital (History 1) and another with elements that are not logical/historical preconditions but which capital nevertheless incorporates, internalizes, and transforms (History 2)'. As this definition also makes clear, Chibber's dichotomous interpretation of History 1 as Western, abstract and universal, and History 2 as Eastern, particular and local, is wide off the mark.

${ }^{79}$ Chakrabarty 2008 , p. 71.

80 Sohn-Rethel 1978.
} 
worker is the precondition for their exchangeability on the market, and hence the precondition for capitalism as such. History 2s can, by contrast, provide 'affective narratives of human belonging where life forms, although porous to one another, do not seem exchangeable through a third term of equivalence such as abstract labour'. ${ }^{81}$ In this way, History $2 s$ do not simply appear as a differentiated functional moment in the development of capitalism. As Marcus Taylor argues, 'while capital may indeed seek to rewrite social life to further the cause of "endless accumulation", it does not do so - to twist a famous maxim - in conditions of its own choosing'. Capital's universalisation must instead be understood as 'a process that constantly inhabits, remakes and is fundamentally remade in its interaction with institutional forms, regimes of value and alternative temporalities that have their lineage in other histories and modes of being'. ${ }^{82}$

The Dialectics of History 1 and 2

Chakrabarty's critique of Marxism's 'blind spot' ${ }^{83}$ is then focused on its inability (or unwillingness) to take History 2 'seriously'. ${ }^{84}$ The Marxist

\footnotetext{
81 Chakrabarty 2010, p. 71.

82 Taylor 2010, p. 5; see similarly, Shilliam 2009, p. 72.

83 Chakrabarty 2008, p. 67.

84 Chakrabarty 2008, p. 69.
} 
analysis of the capitalist mode of production tends to create - and methodologically situate itself within - 'abstract space', which erases 'the local' and 'evacuates all lived sense of place'. ${ }^{85}$ Although History 1 may seek to negate, destroy or sublate History 2, there is no guarantee that 'this could ever be complete'. ${ }^{86}$ Therefore, the correct method, according to Chakrabarty, is to write history in a way that combines History 1s and History 2s, wherein the 'universal history of capital and the politics of human belonging are allowed to interrupt each other's narrative'; and wherein capital's 'histories are History 1s constitutively but unevenly modified by more and less powerful History $2 s^{\prime}{ }^{87}$ Most revealingly, the category through which Chakrabarty seeks to elucidate such 'difference', 'modifications' and 'interruptions' is Marx's (universal) category of real labour, the category that alongside - and in tension with - abstract labour inheres in all commodities in the capitalist mode of production.

It is clear, then, that when Chakrabarty is talking about History $2 s$ - about real labour, about difference - he is doing so in a way that both depends upon and reveals a dialectical relation with History 1s, with abstract labour, and with universality as such. That is, 'just as real labor cannot be thought of outside of the problematic of abstract labor,

\footnotetext{
85 Chakrabarty 2008, p. xvii.

${ }^{86}$ Chakrabarty 2008, p. 65.

87 Chakrabarty 2008, p. 70.
} 
subaltern history cannot be thought of outside of the global narrative of capital'. ${ }^{88}$ As such, it is important to reject Chibber's denunciation that Chakrabarty is providing 'a license for exoticism'. ${ }^{89}$ As Chakrabarty explicitly states, his argument is 'not against the idea of universals as such', but an emphasis on how 'the universal was a highly unstable figure, a necessary placeholder in our attempt to think through questions of modernity'. ${ }^{90}$ Chakrabarty is unequivocal in his description of History 2; these are 'histories that capital everywhere even in the West - encounters as its antecedent, which do not belong to its life process'. ${ }^{91}$ Insofar as History 2 refers to processes and relations 'within the time horizon of capital', ${ }^{92}$ insofar as these can be local or universal, insofar as they are equally relevant to the study of 'the East' as well as 'the West', insofar as History 1 means something other than 'abstract definitions' or 'universals', and insofar as it

\footnotetext{
${ }^{88}$ Chakrabarty 2008, p. 95.

${ }^{89}$ Chibber 2013, p. 238; emphasis in original. To be clear, this is not to deny that some of Chakrabarty's empirical analyses fall prey to such 'exoticism' - of treating local or traditional particularities as unproblematic sites of resistance to capital's universalising reach. This is well exemplified by Chakrabarty's (Chakrabarty 2008, Chapter 8) problematic treatment of the figure of the grihalakshmi (goddess of the house) in Bengali bhadralok's attempts to celebrate Indian cultural difference against the dominance of a universal(ising) colonial modernity (see Bandyopadhyay 2004, p. 183). However, the point we are making here is that Chakrabarty's definition of History 2 cannot be logically reduced to such 'exoticism' or particularities as it explicitly incorporates universal elements and phenomena. We thank an anonymous review for raising this important issue in pushing us to further clarify our position.

${ }^{90}$ Chakrabarty 2008, p. xiii.

${ }^{91}$ Chakrabarty 2008, p. 69; emphasis ours. It is worth noting that by invoking the term 'antecedent', Chakrabarty is not making an exclusively diachronic argument, although he does not deny the possibility of it being used diachronically.

${ }^{92}$ Chakrabarty 2008, p. 95.
} 
identifies concrete processes and social relations, Chibber's following charge is difficult to sustain:

Chakrabarty argues the universalization of capital is a myth, that it is forever incomplete because the actual practice of reproduction in the East does not conform to its abstract description as presented in the works of Marx or other Enlightenment thinkers. And the reason it does not conform to that description is that History 2 forces modifications on it. ${ }^{93}$

Chibber's reading not only misses the subtleties of Chakrabarty's argument, it also imposes a highly contradictory reading of the tensions and antagonisms Chakrabarty elucidates in his own analysis of capital. On the one hand, Chibber insists that Chakrabarty is incorrect to argue History 2 necessarily forces modifications on History 1 , or that the former alters the latter's 'fundamental logic'. Specifically, whatever impact History 2 might have on History 1, the latter's 'rules of reproduction' will not have been 'disturbed, even if the workings, or the form in which they are instantiated, may have been affected to some degree'. ${ }^{94}$ Chibber then highlights the numerous ways in which

\footnotetext{
93 Chibber 2013, p. 227.

94 Chibber 2013, p. 227.
} 
certain History $2 \mathrm{~s}$ are tolerated or wholesale appropriated by capital to facilitate the latter's functioning ${ }^{95}$ The implication here is that the study of History 2 does not carry the weight of significance that Chakrabarty assigns to it.

None of this, however, actually refutes Chakrabarty's argument since, as we have seen, for Chakrabarty commodities and money History $2 s$ - are central to the functioning of capitalism as a mode of production. In other words, Chakrabarty clearly does not envision every aspect of History 2 as necessarily antagonistic to the reproduction of capital. How else could he possibly claim that commodities and money are part of History 2 - 'something belonging to the "cellular" structure of capital'? ${ }^{96}$ Chibber argues, by contrast, that '[e]ven while some relations associated with History 2 might be dysfunctional for capital, it is simply impossible to image that every such relation would have to be. Chakrabarty seems to equate the autonomy of a practice from the logic of capitalism with that practice being corrosive to capitalism'. ${ }^{97}$ Contrast this with what Chakrabarty actually says about History $2 \mathrm{~s}$ :

\footnotetext{
95 Chibber 2013, pp. 236-7.

${ }^{96}$ Chakrabarty 2008, p. 64.

97 Chibber 2013, p. 228; emphasis in original. Chibber here backs this position by arguing that Chakrabarty 'defines History 2 simply as those practices that "do not lend themselves to the logic of reproduction of capital"' (Chibber 2013, p. 228). But compare this with the full quote from Chakrabarty: 'I therefore understand Marx to be saying that "antecedent to capital" [elements of History 2] are not only the relationships that constitute History 1 but also other relationships that do not lend themselves to the logic of reproduction of capital' (Chakrabarty 2008, p. 64; emphasis ours). That is to say, aspects of History 2 can be fundamental to the functioning of capital, without
} 
These relations could be central to capital's self-reproduction, and yet it is also possible for them to be oriented to structures that do not contribute to such reproduction. History 2s are thus not pasts separate from capital: they inhere in capital and yet interrupt and punctuate the run of capital's own logic..$^{98}$

In other words, Chakrabarty is arguing that aspects of History 2 can indeed be fundamental to the functioning of capital, without necessarily constituting part of capital's own 'logical presuppositions'. ${ }^{99}$

But the contradiction in Chibber's argument becomes even more apparent once he insists that there is no necessity within History 1s to subjugate History 2s. ${ }^{100}$ Chibber argues that capital can happily tolerate History 2s autonomously existing side-by-side with History 1s, without the former being 'corrosive' to the latter. ${ }^{101}$ But for Chibber to say this is to deny the very universalising drive that both Marx and Chakrabarty insist exists at the core of capital's 'laws of motion'. It is to

\footnotetext{
necessarily forming part of capital's own 'logical presuppositions' (Chakrabarty 2008, p. 64): again, take Chakrabarty's examples of money and commodity, to which one could also add the 'reproductive sphere', patriarchy, and systemic racism - all of which, we would argue, are constitutive elements of capitalism (see Anievas and Nişancıoğlu 2015).

${ }^{98}$ Chakrabarty 2008, p. 64; emphasis ours. Relatedly, as Chakrabarty writes elsewhere: 'Capitalist production ... has thrived in a variety of cultures, ranging from the most hierarchical to the most democratic. Perhaps we have overestimated capitalism's need or capacity to homogenize the cultural conditions necessary for its own reproduction' (Chakrabarty 2000, p. xiii).

${ }_{99}$ Chakrabarty 2008, p. 64.

100 Chibber 2013, p. 233.

101 Chibber 2013, p. 228.
} 
say that capital does not persistently seek to subordinate processes and social relations not posited by itself to its own logic. It is to deny the multivalent processes of subsumption, expansion, colonisation and accumulation that marks both the logic and history of capitalism ${ }^{102}-$ surely both rather bizarre claims for any Marxist-inspired understanding of capitalism as a totalising mode of production. In short, Chibber's misreading of History 1 and History 2 leads him to make the very argument that he criticises Chakrabarty for: that the universalisation of capital - insofar as it entails more than the simple generalisation of market-dependency ${ }^{103}$ - is wholly a myth.

Resistance to Capital: History 1, 2 or Both?

Chibber, however, offers one way out of this contradiction. He argues that since there is no necessary antagonism between History 1 and History 2, History 2 cannot (necessarily) destabilise History 1. Rather, the universalising tendency of capital is limited because it is

\footnotetext{
102 Chibber claims 'the motivation behind this assault on the worker comes from the threat posed by History 2', therefore, '[Chakrabarty] is asserting that capital will not tolerate in its workers any vestige of local customs, practices, or expectations that do not conform to its functional requirements' (Chibber 2013, pp. 235, 237). But Chakrabarty does not say this. What he does say is that labour processes under capitalism tend to subsume, subjugate and thus abstract from History 2s. This is not a controversial argument for a Marxist. Whether the motive is to destroy History 2, or extract surplus or tickle kittens, is neither here nor there. To deny that the labour process does subjugate and thus abstract from the lives of the individual worker is to deny a basic premise of Marx's theory of capital - i.e. abstract labour.

103 Chibber 2013, p. 111.
} 
'destabilized by elements internal to History 1', a possibility that 'Chakrabarty never seriously considers'. ${ }^{104}$ Putting aside the fact that Chakrabarty devotes a whole subsection in Provincializing Europe titled 'Abstract Labour as Critique' where he does exactly this (and see also the above quotes drawing on Marx), let us examine Chibber's own claim that elements internal to History 1 can destabilise capital.

Chibber suggests that the primary source of instability in capitalism comes from workers opposing capital, from the former seeking to assert their 'wants and needs' against the latter. He then goes on to highlight that such wants and needs drove subaltern struggles to limit the length of the working day, which subsequently led to a systemic abandonment of the capitalist strategy of extracting absolute surplus value, moving capital to a strategy of extracting relative surplus value. Hence, History 1 s were modified and limited not by History $2 \mathrm{~s}$, but by History $1 \mathrm{~s}$ - that is, by workers. As Chibber puts it: 'If there is any genuine source of opposition to capital's universalizing drive, it is the equally universal struggle by subaltern classes to defend their basic humanity'. ${ }^{105}$

Interestingly, this argument bears some striking similarities with the one offered by Chakrabarty,

\footnotetext{
104 Chibber 2013, p. 230.

105 Chibber 2013, p. 233; emphasis ours.
} 
subaltern histories do not refer to a resistance prior and exterior to the narrative space created by capital; they cannot therefore be defined without reference to the category 'capital'. Subaltern studies ... can only situate itself theoretically at the juncture where we give up neither Marx nor 'difference', for ... the resistance it speaks of is something that can happen only within the time horizon of capital, and yet it has to be thought of as something that disrupts the unity of that time. Unconcealing the tension between real and abstract labor ensures that capital/commodity has heterogeneities and incommensurabilities inscribed in its core. $^{106}$

There is one difference between Chakrabarty and Chibber, however, since the former sees subaltern resistance situated in the (universal) category of 'real labour'; that is, History 2. For it is the antagonism between abstract labour (History 1) and real labour (History 2) that Chakrabarty considers to be at the heart of his Marx-inspired research programme.

${ }^{106}$ Chakrabarty 2008, p. 95. 
In contrast, due to his misapprehension that 'History $1=$ universals', Chibber argues that subaltern resistance is a part of History 1, and as a consequence feels compelled to invoke the universality of human nature - 'the interest in well-being'107 as the source of workers' resistance and opposition to capital. But this characteristic, by virtue of it being based on an a priori conception of human nature, by virtue of it being something antecedent to that which is posited by capital, is indeed, can only be - part of History 2. To claim otherwise - to claim human nature is History 1 - is to argue that capital posits human nature as part of its own life-process, bringing Chibber suspiciously close to ideologues who argue capitalism is merely an expression of human nature. It is also to claim that capital posits 'the interest in well-being' as 'part of its own life-process'. But if anything the whole point of the Marxist critique of capitalism is that the opposite is true - capital neither expresses human nature, nor does it fulfil the interests of 'basic humanity' and 'well-being'. There is, then, much at stake in retaining some of the insights gleaned from Chakrabarty's interpretation of Marx. For his emphasis on the tensions between History 1s and History $2 \mathrm{~s}$ appears crucial to mitigating against the potentially ahistorical, essentialising and (economically) homogenous reading of

107 Chibber 2013, p. 231. 
capitalism and the resistance to it found in Chibber's alternative. While

Chibber is very careful, as he continually insists, not to deny that all sorts of social and cultural differences can exist under capitalism, ${ }^{108}$ his conception of what capital's universalisation actually entails tells us very little about the differential dynamics of capitalism or the struggles generated by it within any particular locale. ${ }^{109}$ The question that must be asked is then: What tools does Chibber's alternative conceptualisation provide Marxists in understanding and theorising difference? Very few it seems. Yet surely this is an important component for developing concrete political strategies and tactics in different sociopolitical and cultural contexts. Moreover, given that the study of sociohistorical difference is the defining problematic of postcolonial theory, Chibber's failure to elaborate any alternative

\footnotetext{
${ }^{108}$ As he makes clear, 'capitalism is perfectly compatible with a diverse set of political and cultural formations' while also noting that capitalism is in fact 'not only consistent with great heterogeneity and hierarchy, but systematically generates them' (Chibber 2013, p. 285; see similarly pp. 150-1 and 243-6).

109 In addition, the idea that capitalism's universalisation should be conceived as the generalisation of a 'reproductive shift toward market dependence' among economic units (Chibber 2013, p. 110) begs the question of the accuracy of this description in understanding the real history of capitalist development and its expansion. Is it really the case that oligopolistic and state-run forms of enterprise are market-dependent in any meaningful sense? Under oligopolistic market conditions, is it not the market that is more dependent on and determined by the dominant firms, rather than the other way around? And what about the role of state interventionism more generally? Can any of these aspects of 'really existing capitalism' be accounted for in a satisfactory way by Chibber's Political Marxist-inspired conception of capital's universalising tendency? In critiquing the Political Marxist conception of capitalism, Neil Davidson argues (Davidson 2012, p. 418) that "pure" capitalist social property relations have never been completely dominant anywhere, nor - unless socialists completely fail in their objectives - will they ever be'. Nonetheless, for Chibber's analysis, the answers to these questions are unclear given the level of analytical abstraction he formulates his conception at.
} 
conceptual framework besides a brief run through some previous

Marxist attempts is a rather strange and problematic omission.

For the above reasons, the kind of method Chakrabarty proposes strikes us as an altogether positive advance for scholars going about writing the history of capitalism. ${ }^{110}$ Taking a multiple and differentiated agency as a starting point, and subsequently exploring encounters and interactions within this multiplicity is the kind of approach Marxists should embrace, not reject. It is therefore worth briefly noting some of the affinities between Chakrabarty's approach (and postcolonialism more broadly) and the theory of uneven and combined development, while demonstrating how Trotsky's idea assists in redressing some fundamental shortcomings of postcolonial theory. ${ }^{111}$

\footnotetext{
110 We have sought to construct a history of the making of capitalism in which the sorts of histories targeted by 'History 2' - specifically those found in the 'unwaged' or 'reproductive' sphere - are understood as constitutive of 'History 1' - the formation of 'abstract labour' and an industrial proletariat as such (Anievas and Nişancıoğlu 2015).

${ }_{111}$ Although Chibber himself invokes Trotsky's idea at the very end of Postcolonial Theory as one of a number Marxist attempts to 'understanding the specificity of the East' (Chibber 2013, p. 291), he does not employ the theory in developing any of his substantive critiques of Subaltern Studies. Neil Lazarus (Lazarus 2016, p. 106) finds this absence of the theory of uneven and combined development in the 'main body of his [Chibber's] study' a 'failure that simply baffles understanding'. On one level this is true: how could Chibber not draw on a concept that is so applicable in making his case against postcolonialism? On another level, however, it makes sense given that the entire thrust of Trotsky's theory is to illuminate and articulate the interactively-generated developmental differences between societies and the sociological amalgamations within societies that problematise and transcend the kind of abstract definitions of capitalism and static comparative perspectives provided by Chibber and the theoretical frameworks upon which he draws (cf. Murphet 2014, pp. 161-2). For Marxist critiques of postcolonialism that employ uneven and combined development in a more systematic way, see Matin 2013 and Kaiwar 2014.
} 


\section{The Limits of Postcolonial Theory}

Postcolonialism and Uneven and Combined Development

To begin with, positing a 'not-yet' to 'backward' peoples was a prevalent and distinctly 'historicist' sentiment within Russia precisely at the time Trotsky was developing the theory of uneven and combined development. Pointedly, Trotsky rejected the Menshevik idea of 'waiting' for a bourgeois stage before a proletarian revolution could occur and insisted on the 'now'. The Bolshevik Revolution and strategy of permanent revolution are direct outcomes of this, while uneven and combined development was its methodological and theoretical foundation. This is especially revealing given the centrality of the peasant - the supposedly non-modern agent par excellence - in Russian social life generally, and the Bolshevik Revolution specifically. In the History of the Russian Revolution, Trotsky's explicitly characterises Russia's revolutionary conditions in terms of the imbalance between town and country, and revolutionary agency in terms of the combination of a newly-formed industrial proletariat and the pre-existing peasantry. We can trace this back even further to Marx, who himself saw the potential for a communist revolution in 
Russia ahead of the capitalist heartlands due to the very prevalence and dominance of the peasant commune..$^{112}$

The reason both Marx and Trotsky identified forms of divergence and differences similar to those found in the postcolonial literature was because both were sensitive - with some important limitations ${ }^{113}$ - to the intersection of History 1s and History 2s. As we shall see, it is through the idea of 'combination' that Trotsky's theory provides a nonstadial, multilinear understanding of development that explicitly denies essentialised and externally related dichotomies of pre-capitalist and capitalist. Similarly, we find in Marx an outright rejection of any 'suprahistorical' application of his categories in Capital. This was because 'events strikingly analogous but taking place in different historic surroundings led to totally different results' and thus could not be explained 'by the universal passport of a general historicophilosophical theory'. ${ }^{114}$ The explicit (if still partial) disavowal of historicism (in Chakrabarty's meaning of the term) in the writings of Trotsky and Marx should therefore alert us to the possibility that

\footnotetext{
$112<$ https://www.marxists.org/archive/marx/works/1881/zasulich/index.htm >. [hyperlink dead $\mathrm{MC}]$

113 It is notable, for example, that neither Marx nor Trotsky integrated the analysis of the non-waged sphere into their analysis of capitalism in any systematic way. This has led some Marxists to see relations of patriarchy and white supremacy as mere ideological functions of the otherwise economic logic of capitalism. Such reductionism has been forcefully challenged by an array of authors working from the perspectives (for want of better terms) of critical gender and race theory, who have emphasised that both patriarchy and racism must be viewed as sets of class relations. See e.g. Delphy and Leonard 1984; Mills 1997; Alcoff and Fraser 2005; Federici 2012. 114 <https://www.marxists.org/archive/marx/works/1881/zasulich/index.htm> >
} 
postcolonialism and Marxism need not be seen as mutually exclusive endeavours.

With this in mind, we suggest that uneven and combined development provides a theoretical approach that strengthens the broader aims of the postcolonial research programme. We make this suggestion because there remains a tension within postcolonialism that ultimately undermines its efforts in both fully subverting Eurocentrism and reinserting non-European agency into the history of capitalism. The tension is rooted in the parochial - dare we say 'provincial' - scope of its critique; that is, their subject rarely extends beyond the particular experience of modernity in specific localities and, particularly, those experiences in the colonial modernities of the Global South. Thus, Chakrabarty notes that 'Provincializing Europe is not a book about the region of the world we call "Europe"', ${ }^{115}$ but is instead concerned with the generalisation of its forms and categories. Similarly, Chatterjee says: '[t]he universality of Western modernity ... is a product of its local conditions', which is then subsequently 'transported to other place and times' ${ }^{116}$ Consequently, both authors uncritically presuppose a discreet and hermetically-sealed European history in which modernity was uniquely created before being

\footnotetext{
115 Chakrabarty 2008, p. 3.

${ }^{116}$ Chatterjee 2010, pp. 296-7.
} 
subsequently expanded globally which is then the primary focus of their analyses. ${ }^{117}$ Such a view is an integral part of the myth of Europe as an exceptional, pristine and autonomous entity that happened to be especially well suited to the transition to, and spread of, capitalism. ${ }^{118}$ Insofar as 'the West is constituted as an imperial fetish, the imagined home of history's victors' and 'the embodiment of their power', ${ }^{119}$ many of the processes of developmental differentiation that created hierarchical imbalances between colonisers and colonised are occluded. ${ }^{120}$

Guha's 'Dominance without Hegemony' Reassessed

In these ways, we find in postcolonial works a lack of any substantive engagement with the question of how capitalism emerged and developed in Europe in the first place. This is a-perhaps the - critical lacuna of postcolonial theory. Take, for example, Ranajit Guha's classic analysis of Indian colonial modernity in Dominance without Hegemony and Chibber's critique of it. Guha argues that capitalist modernity in India diverged from the experience of modernity in the

\footnotetext{
117 Cooper 2005, p. 20.

118 For two notable exceptions, see Bhambra 2007 and Shilliam 2009.

119 Coronil 1996, pp. 77-8; see similarly, Lazarus 2002.

120 Cf. Dirlik 1997; Lazarus 2011.
} 
West, creating a distinct form of political rule - 'dominance without hegemony'. This in turn forms the foundation for Guha's key argument regarding 'the failure of the Indian bourgeoisie to speak for the nation'121 - that it failed 'to successfully integrate the culture of the disparate groups in Indian society into one all-embracing political community'. According to Chibber, such an argument is necessarily a contrastive claim requiring a comparative analysis of some sort. ${ }^{122}$ This is so because the 'peculiarity' of the Indian bourgeoisie constituting their 'failure' as such, Chibber argues, 'simply cannot be understood without reference to some events which comprise the norm, or the standard, against which the peculiarities of colonialism can be understood'. ${ }^{123}$

Chibber goes on to claim that the norm or standard from which to make this comparative contrast that Guha himself provides is that of the English and French bourgeois revolutions of the seventeenth and eighteenth centuries respectively. ${ }^{124}$ Chibber argues that 'Guha's historical sociology'125 of these events is mistaken, drawing as it does on a now 'discredited historiography of the European revolutions'. As a consequence, Guha's broader claims regarding the 'putative gap

\footnotetext{
121 Guha 1982, p. 5.

122 Chibber 2013, pp. 33, 34.

123 Chibber 2014a, p. 83.

124 Chibber 2013, pp. 54-5.

125 Chibber 2013, p. 102.
} 
between the competency of Indian and western European capitalists ... [is] largely fictional'. ${ }^{126}$ In substantiating these points, Chibber then offers his own synthesised, alternative historical sociology of these revolutions $^{127}$ drawing on the latest (predominately 'revisionist') historiographical literatures in showing that neither the English nor French experiences could be defined as "bourgeois revolutions" in the sense that Guha uses the term'. ${ }^{128}$

Here we leave aside the substance of Chibber's historical analysis and instead focus on the relevance of these claims for both the Subaltern project and Chibber's critique of it. Chibber writes:

\begin{abstract}
At the heart of the Subalternist project, and of postcolonial theory more generally, stands the claim that there is a deep fault line separating Western capitalist nations from the postcolonial world. The importance of Ranajit Guha's work is that it offers a historical sociology that seeks to explain how and why this fault line came into being. ${ }^{129}$
\end{abstract}

\footnotetext{
${ }^{126}$ Chibber 2014a, p. 82.

127 See Chibber 2013, pp. 54-79.

128 Chibber 2013, p. 55; For the reasons why the English and French revolutions cannot be considered 'bourgeois revolutions' in Guha's sense (or, for that matter, in the classical Marxist sense), see pp. 76-9. We have provided an analysis of these revolutions that refutes many of Chibber's historical arguments while drawing on a wider and more diverse range of perspectives in the historiographical literature than his own (Anievas and Nişancıoğlu 2015, Chapter 6).

129 Chibber 2013, p. 50.
} 
The significance of Guha's historical sociology of the early bourgeois revolutions in Europe for Chibber's own critique of the Subaltern project is further brought out by Chibber when he writes that if the wider arguments in the Subalternist oeuvre are to be assessed, the first requirement is an appraisal of the historical sociology on which they rest, as developed by Guha'. ${ }^{130}$ Indeed, Chibber's key claim as to the originality of his critique of postcolonial theory is that it primarily focuses on the 'Subalternists' historical sociology, particularly their understanding of the East-West divergence - a subject crucial to their project, albeit one that has garnered very little attention'. ${ }^{131}$

Chibber's critique of Guha's historical sociology is therefore fundamental to his broader criticisms of the Subaltern project and postcolonialism more generally. However, as a number of Chibber's critics have argued, no such historical sociological account of the early bourgeois revolutions in Europe actually exists in Guha's text. ${ }^{132}$ For the main aim of Guha's text was, according to Chatterjee, 'a critique of liberal historiography and the liberal ideology it represented and not [...] a historical sociology of bourgeois revolutions of Europe as

\footnotetext{
130 Chibber 2013, p. 26.

131 Chibber 2013, p. 22.

132 See Chatterjee 2013; Seth 2014. By contrast, Gayatri Chakravorty Spivak has criticised Chibber for the audacity to even question such a 'primary text' as Guha's Dominance without Hegemony, sardonically asking: 'Would Professor Chibber correct Rosa Luxemburg and DD Kosambi? No, because he knows they are primary texts' (Spivak 2014, p. 190) - a ridiculous claim that Chibber rightly takes to task as dogmatic nonsense in his reply (Chibber 2014b, pp. 619-22).
} 
Chibber understands it to be'. What Guha sought to draw out in the first chapter of Dominance without Hegemony were two key claims made by liberal ideology and its historiographical articulations. ${ }^{133}$ The first regards the universalisation of capital highlighted in this hegemonic liberal narrative, and the second concerns their representations of the English and French revolutions in establishing bourgeois hegemony in the sense of the class's ability to 'speak for all of society'. ${ }^{134}$ Guha quotes Marx on this 'achievement' of the early bourgeois revolutions, which Chibber cites as evidence of Guha's historical sociology of these events. However, Guha does so in order to argue that, if taken in isolation from Marx's broader critique of capitalism, such claims would render Marx nearly 'indistinguishable' from many nineteenth-century liberal ideologues. Thus, nowhere does Guha actually 'offer any propositions of his own that might be construed as a historical sociology' of such revolutions. ${ }^{135}$

Chatterjee's interpretation of Guha's work is broadly shared by Sanjay Seth (a former PhD student of Guha) who argues that he never provided the putative historical sociology Chibber ascribes to him. Instead, Guha's central endeavour was to demonstrate how Britain's colonial rule of India 'did not and could not rest on the consent that it

\footnotetext{
133 Chatterjee 2013, p. 69.

134 Guha 1997, p. 134.

135 Chatterjee 2013, p. 69.
} 
claimed for itself at home' and that the elites who took power after India's independence could not either; that is, the Indian bourgeoisie could only achieve 'dominance without hegemony'. ${ }^{136}$ The object of Guha's critique was then the co-constitutive constructions of East and West by liberal historiography and its derivative discourses through a conception of European history as universal history. ${ }^{137}$

What are we to make of such claims? Did Guha intend to offer a historical sociology of the English and French bourgeois revolutions as a 'contrastive comparison' to his claims about postcolonial India? And, if not, did he logically need to in substantiating his broader arguments?

While Chibber and his critics' contrasting interpretations of Guha are never quite as clear-cut as either of them makes them out to be, it would seem that Chatterjee and Seth's reading is the more plausible one. In his reply to Chatterjee, Chibber chastises him for failing to provide 'any textual evidence' in support of his alternative interpretation of Guha or any engagement with the textual evidence that Chibber himself adduces in substantiating his claims. And Chibber is absolutely correct: Chatterjee does neither of these things. So what happens when we do engage with the textual evidence from Guha that Chibber provides?

\footnotetext{
136 Seth 2014, p. 1218; emphasis ours.

137 Roy 2015, pp. 3-4.
} 
Let us look at a few of the most important pages of Dominance without Hegemony ${ }^{138}$ that Chibber singles out in challenging Chatterjee's asserted counter-interpretation, where he claims Guha makes it 'abundantly clear' that he intends to offer a comparative 'norm' or 'standard' (i.e. the European bourgeois revolutions) from which to draw out and critically examine the 'peculiarities of colonialism'. ${ }^{139}$ Despite Chibber's claim that these pages support his reading, Guha's discussion in these pages appears to contradict Chibber's interpretation. This is above all evinced in Guha's explicit discussion of his particular method and object of critique where he makes clear that his methodological approach is an exclusively historiographical one that aims to reflect 'on the character of colonialist historiography and show how it has sought to endow colonialism with a spurious hegemony denied it by history'. ${ }^{140}$ This point is reiterated on the next page, where Guha writes:

Our approach to these problems [specifically, the failure of the Indian bourgeoisie to speak for the nation and thus achieve hegemony] picks its way through historiography, as the readers will notice no doubt from the signs displayed all

\footnotetext{
138 Guha 1997, pp. xi-xiii, 3-5.

139 Chibber 2014a, p. 83.

140 Guha 1997, p. xii.
} 
over the text and the arguments these refer to. We have taken this particular course not out of any conviction that this is the only possible way of asking questions about colonialism and the colonial state ... But we have decided on the historiographical approach primarily because it helps us to combine the advantages of the classical theories [of political philosophy] with a consideration of history as writing. The importance of the latter for our problematic is hard to exaggerate. For at a certain level the question of power in colonial South Asia or anywhere else in a land under foreign occupation can be phrased succinctly as "Who writes the history of the subjugated people?'. ${ }^{141}$

It appears, then, that Guha's work is intended as an immanent critique of liberal ideology - in both colonial and postcolonial forms - and its corresponding hegemonic historiographical tendencies represented by rival colonial and nationalist historians in India. As such, Guha's critical 'historiographical approach' operates at the purely discursive or narrative-centred level. It seeks to demonstrate that the failure of the

\footnotetext{
${ }^{141}$ Guha 1997, p. xiii; emphasis ours. Further in regard to the importance of this historiographical approach, Guha writes: 'Our attempt to inform this study of colonialism by the pathos of a purloined past is therefore not so much a matter of professional convenience as a strategy to situate the writing of a conquered people's history by conquerors at the very heart of the question of one nation's oppression by another' (Guha 1997, p. xiv).
} 
British bourgeoisie in ruling colonial India and their Indian counterparts after independence 'to measure up to the heroism of the European bourgeoisie in its period of ascendancy' ${ }^{\prime 142}$ is, for Guha, the standard or norm from which to critique it as presented by liberal ideologues and their historiographical representations. In other words, the 'contrastive comparison' that Guha is making is one internal to liberal ideology and its historiographical representations of European history.

From this perspective, Guha takes aim at the shared presumption of a 'unitary political domain' ('Civil Society $=$ Nation $=$ State') derivative of the hegemonic form of rule that Britain claimed for itself at home - that colonial and nationalist historiographies read into the Indian past. ${ }^{143}$ In contradistinction to this 'enigma' common to 'both of those rival ideologies' which Guha takes as his 'point of departure', he argues that the "colonial state in South Asia was very unlike and indeed fundamentally different from the metropolitan bourgeois state which had sired it'. ${ }^{144}$ Guha is therefore essentially holding up the British colonial and Indian bourgeoisie and critiquing them in the mirror of their own ideological and historiographical constructions. In his own words:

\footnotetext{
142 Guha 1997, p. 5.

143 Guha 1997, pp. xi-xii.

144 Guha 1997, p. xii.
} 
we present our views on the structure of dominance in colonial India and historiography's relation to it as a critique of our own approach to the Indian past and our own performance in writing about it. The purpose of this work is, therefore, simply to stimulate a degree of self-criticism within the practice of Indian historiography. What calls for such selfcriticism is our complicity with colonialist historiography. ${ }^{145}$

Guha seems content not to offer any substantive historical sociology of these events himself. Instead, Guha only provides an exposition of different elite-based historiographical accounts of the Indian colonial and postcolonial state. But significantly, before doing so, he turns to a discussion of the liberal ideological and historiographical critique of feudalism in the era of its demise and the ascendancy of the bourgeoisie. ${ }^{146}$ What he is seeking to elucidate here is where an 'uncompromising critique' of a ruling order (e.g. feudalism, capitalism, etc.) might come from. Guha answers: '[f]rom outside the universe of dominance which provides the critique with its object, indeed, from another and historically antagonistic universe'. ${ }^{147} \mathrm{He}$ then raises a question of 'fundamental importance' to his analysis: where 'does the

\footnotetext{
145 Guha 1997, p. 96.

146 Guha 1997, pp. 11-13.

147 Guha 1997, p. 11.
} 
critique of liberalism itself come from?'. Again, the answer is that it comes from 'an ideology that is antagonistic towards the dominant culture and declares war on it even before the class for which it speaks comes to rule', an ideological critique that organically 'arises from the real contradictions of capitalism and anticipates its dissolution'. ${ }^{148}$ Guha then lays out one such contradiction - the universalising tendency of capital - that 'serves as a basis for the critique of a bourgeois culture in dominance'. He argues that Marx's conceptualisation of capital's universalising tendency is

not about expansion alone, but about an expansion predicated firmly and inevitably on limitations capital can never overcome; not simply about a project powered by the possibility of infinite development, but a project predicated on the certainty of its failure to realize itself. ${ }^{149}$

Marx's critique of capital's universalising drive as a necessarily limited and incomplete forms the launching-pad for Guha's subsequent analysis. But, as should be clear, Guha's argument throughout remains an expository one; it operates at the discursive level 
examining different hegemonic and counter-hegemonic ideologies, historiographical representations, and critiques.

Having established this ideological and historiographical context and the nature of his critique in the preface and opening pages of the book, Guha goes on to make various comparative contrasts between the European and Indian bourgeoisie and their political orders without actually having to make any substantive historical sociological claims of his own. On this interpretation, it then makes sense that Guha's discussion of the English and French revolutions would take the form of 'highly compressed statements' that are continually 'presented in the form of an assertion, not an argument' ${ }^{150}$ for which Guha provides no supporting references to any contemporary historical works or wider body of historiographical literature. And why should he if the aim of the study was an internal critique of liberal ideological narratives and historiographies? The normative benchmark for Guha's critique of liberal historiography is their own self-representations of the role of the bourgeoisie in Europe and India and the types of political orders they produced. It is then the 'real' contradiction inhering in capital's own universalising tendency which constitutes the material conditions from 
which such an ideological critique - indeed, Marx's critique - could emerge. ${ }^{151}$

Hence, the quotations Chibber produces from Guha to credit him with a 'historical sociology' of the early bourgeois revolutions turn out to be - when read in this broader context and structure of Guha's work - Guha's critical exposition of other writers' analyses (both liberals and Marx). This reading also makes sense when Guha speaks of the 'heroism of the European bourgeoisie in its period of ascendancy' as it seems that Guha is here being deliberatively ironic in using the very characterisation of the European bourgeoisie ('heroism') as presented by their liberal ideologues and corresponding historiographies.

The Lacuna of Postcolonial Theory

Though the historical sociology that Chibber finds in Guha does not appear to exist, one could certainly forgive him for thinking it did. For Chibber's other key point regarding the logical necessity of Guha providing some historical 'contrastive comparison' in understanding the 'peculiarities' of the colonial and postcolonial Indian state and its

\footnotetext{
151 As Guha reiterates (Guha 1997, p. 20): 'the critique of historiography should begin by questioning the universalist assumptions of liberal ideology and the attribution of hegemony taken for granted in colonialist and nationalist interpretations of the Indian past. It must begin, in short, by situating itself outside the universe of liberal discourse'.
} 
bourgeois representatives remains valid. Chibber's critique of the 'Subalternist oeuvre' that rests on Guha's work is in this regard broadly correct; though not quite in the way Chibber intended. That is to say, the lack of any historical sociological account of the ascendancy of bourgeois dominance and the origins of capitalism in Europe more generally in the Subalternist oeuvre limits their ability to fully transcend the Eurocentric modes of analysis they so forcefully critique. It is this absence that constitutes the fundamental shortcoming of the Subaltern project and postcolonial studies as a whole. It unintentionally leads them to present a highly idealised picture of European development as endogenously giving birth to capitalist modernity from where it subsequently spread outward that does not accord with the historical evidence. The West is thereby endowed with hyper-fetishised agential powers - the sole and sovereign author of their own history. ${ }^{152}$

Despite acknowledging the significance of capitalism as a force of history, postcolonialism's lack of engagement with the historical origins of capitalism lends itself to a conception of capitalism that is 'decidedly singular and decidedly European'. ${ }^{153}$ This in turn runs the risk of reproducing the Orientalist trope that the specificities of "Oriental" states and societies are subordinate to the all-encompassing 
and irreducible categorisation of their being Oriental'. ${ }^{154}$ The emphasis on such 'specificity', moreover, tends to overlook the very processes of developmental differentiation that created hierarchical imbalances between colonisers and colonised in the first place. ${ }^{155}$ So, while additional empirical frameworks gleaned from the postcolonial approach have decentred many Eurocentric presuppositions, these theoretical presuppositions have remained intact and at worst actively replicated. ${ }^{156}$

To modify Frederick Cooper's call to arms: in order to truly 'provincialise' Europe one must dissect European history itself, and there is no more central myth to be dissected than that of narrating European history around the history of capitalism. ${ }^{157}$ As Kamran Matin argues, such a task ultimately requires 'a general social theory, and not just a theory of modernity', one 'that goes beyond a mere phenomenology of capital's expansion and comprehends capital itself as a product of the interactive multiplicity of the social'. ${ }^{158}$ This demands a genuinely 'internationalist historiography'159 and theorisation of capitalism's emergence and reproduction; one that could 'distinguish between the inflated, utopian self-presentation of capital as abstract

\footnotetext{
154 Bryce 2013, p. 100.

155 Cf. Dirlik 1997; Lazarus 2011.

156 Halperin 2006, p. 43.

157 Cooper 2005, p. 22.

158 Matin 2013, p. 364.

159 Banaji 2010, p. 253. [now inserted into bibliography - MC]
} 
and homogenous and the contradictions internal to historical capitalism that produce a global, differentiated, and hierarchical space-time'. ${ }^{160}$ For the very conditions giving rise to capitalist social relations within Europe over the longue durée were often rooted within and emanating from non-Western sources and agents. ${ }^{161}$

Such an 'internationalist' perspective is, we argue, provided by the theory of uneven and combined development. By positing the multilinear character of development as its 'most general law', ${ }^{162}$ uneven development provides a necessary corrective to any ontologically singular conception of society ${ }^{163}$ and associated unilinear conceptions of history that underpin Eurocentric accounts. By positing the intrinsically interactive character of this multiplicity, combined development in turn challenges the methodological internalism of Eurocentric approaches while the very concept of combination denotes that there has never existed any pure or normative model of development. ${ }^{164}$ As such, the theory rejects Eurocentrism's reified conceptualisation of the universal as an a priori property of an

\footnotetext{
160 Goswami 2004, p. 40.

161 See Anievas and Nişancıoğlu 2015.

162 Trotsky 2008.

163 That is to say, the derivation of societal multiplicity ('the international') from the properties of a unitary social form (for example, slavery, feudalism, capitalism, etc.). Consequently, while 'international' (or intersocietal) phenomena may be permitted all kinds of contingent empirical significance in a given analysis, they do not factor into the theorisation of what constitutes a society as such. See Rosenberg 2006. This problem of ontological singularity is reproduced by Chibber in his critique of postcolonialism and elsewhere: see especially, Chibber 2011.

164 See Anievas and Nişancıoğlu 2015.
} 
immanently conceived homogeneous entity. For the 'historical reality' of uneven and combined development ${ }^{165}$ is a 'universally operational causal context' whose ontological fabric is simultaneously generative of and shaped by intersocietal alterity. ${ }^{166}$ This is an approach that conceptualises the specificities of any given society as representing 'an original combination of the basic features of the world process' - a 'social amalgam combining the local and general' that is 'nothing else but the most general product of the unevenness of historical development, its summary result, so to say'. ${ }^{167}$ It thereby allows for a conception of the universal that is amenable to and constituted by difference itself. ${ }^{168}$

\section{Conclusion}

In this article, we have sought to reassess the potential merits and pitfalls of postcolonial theory - and, in particular, the Subaltern project - through the prism of Vivek Chibber's Marxist-inspired critique of it. In so doing, we have demonstrated some of the problems with Chibber's

\footnotetext{
165 Trotsky 1972, p. 116.

166 Matin 2013, p. 368.

167 Trotsky 1962, p. 23; Trotsky 1969, p. 56; Trotsky 1962, p. 24.

168 Cf. Matin 2013.
} 
critique which, we argue, must be overcome in order to properly appreciate both the strengths and weaknesses of the postcolonial critique of Eurocentrism, opening the way for new and more constructive engagements between Marxism and postcolonialism. As we have shown, Leon Trotsky's idea of uneven and combined development provides one potentially fruitful avenue of engagement and critique. ${ }^{169}$ This is a concept that has undergone an unprecedented intellectual revival over the last two decades, particularly in the field of International Relations and historical sociology, where scholars have sought to further draw out the implications of uneven and combined development in offering a nonEurocentric social theory of 'the international'. ${ }^{170}$

For implicit in Trotsky's idea was a reconceptualisation of all development as necessarily interactive and multilinear. This essentially redefined the very concept and logic of development itself. Whereas the classical sociological tradition conceptualised society as a singular abstraction, ${ }^{171}$ Trotsky's conception of development was inscribed with a 'more-than-one' ontological premise. ${ }^{172}$ This then cleared the way for an entirely 'new understanding of human history'173

\footnotetext{
169 See further, Murphet 2014; Nilsen 2015; Lazarus 2016.

170 For a list of some of these contributions, see $<$ http://www.unevenandcombineddevelopment.wordpress.com/writings/>.

171 Cf. Tenbruck 1994; Rosenberg 2006.

172 Rosenberg 2013, pp. 581-3.

173 Löwy 1981, p. 87.
} 
breaking with any Eurocentric, 'historicist mode of thinking', as Chakrabarty terms it, that visualises development as 'the secular, empty, and homogenous time of history'. ${ }^{174}$

In its appreciation of societal multiplicity and difference, uneven and combined development provides a way of capturing the nonlinearity of development that is so central to displacing Eurocentric accounts. As such, it shares many affinities with postcolonial approaches. In particular, uneven and combined development provides a particularly fertile framework through which the sort of interconnections between History $1 \mathrm{~s}$ and History $2 \mathrm{~s}$ emphasised by Chakrabarty might be identified, explored and explained. However, beyond Chakrabarty and the Subaltern project, the advantage of uneven and combined development lies precisely in its broader temporal scope. This uniquely positions it as a framework through which we may reconstitute the master categories of Eurocentrism such as capitalism and modernity - on the very terrain they were purportedly generated: that of Europe. ${ }^{175}$

A Marxist critique of postcolonial theory should not simply dismiss the problematic of sociohistorical difference postcolonial scholars have raised and the implications this holds in furnishing a

\footnotetext{
174 Chakrabarty 2008, p. 23, paraphrasing Walter Benjamin.

175 See Anievas and Nişancıoğlu 2015 and 2016.
} 
genuinely non-Eurocentric theory of history. For the Marxist tradition provides invaluable resources in incorporating the strengths of the postcolonial critique of Eurocentrism, whilst transcending its limitations.

\section{References}

Acharya, Amitav 2011, 'Dialogue and Discovery: In Search of International Relations Theories beyond the West', Millennium Journal of International Studies, 39, 3: 619-37.

Ahmad, Aijaz 1992, In Theory: Classes, Nations, Literatures, London: Verso.

Ahmed, Talat 2014, 'Theories of Difference: The Subaltern Project Examined', International Socialism, II, 144, available at: $<$ http://isj.org.uk/theories-of-difference-the-subaltern-projectexamined/>.

Alcoff, Linda and Nancy Fraser 2005, Visible Identities: Race, Gender, and the Self, Oxford: Oxford University Press.

Anderson, Perry 1992, English Questions, London: Verso.

Anievas, Alexander and Kerem Nişancıoğlu 2015, How the West Came to Rule: The Geopolitical Origins of Capitalism, London: Pluto Press.

Anievas, Alexander and Kerem Nişancıoğlu 2016, 'Why Europe? AntiEurocentric Theory, History, and the Rise of Capitalism', Spectrum: Journal of Global Studies, 8, 1: 70-98.

Banaji, Jairus 2010, Theory as History: Essays on Modes of Production and Exploitation, Historical Materialism Book Series, Leiden: Brill.

Bandyopadhyay, Sekhar 2004, Caste, Culture and Hegemony: Social Dominance in Colonial Bengal, New Delhi: Sage Publications.

Bartolovich, Crystal and Neil Lazarus (eds.) 2002, Marxism, Modernity, and Postcolonial Studies, Cambridge: Cambridge University Press.

Bhabha, Homi K. 2012, The Location of Culture, London: Routledge. 
Bhambra, Gurminder K. 2007, Rethinking Modernity and the Sociological Imagination, London: Routledge.

Bhambra, Gurminder K. 2011, 'Talking among Themselves? Weberian and Marxist Historical Sociologies as Dialogues without "Others"', Millennium, 39, 3: 667-81.

Blaney, David and Naeem Inayatullah 2010, Savage Economics: Wealth, Poverty, and the Temporal Walls of Capitalism, New York: Routledge.

Brennan, Timothy 2014, Borrowed Light: Vico, Hegel, and the Colonies, Stanford: Stanford University Press.

Bryce, Derek 2013, 'The Absence of Ottoman, Islamic Europe in Edward W. Said's Orientalism', Theory, Culture \& Society, 30, 1: 99-121.

Chakrabarty, Dipesh 2000, Re-Writing Working Class History: Bengal 1890-1940, Princeton, NJ.: Princeton University Press.

Chakrabarty, Dipesh 2005, 'Subaltern Studies and Postcolonial Historiography', Nepantla: Views from South, 1, 1: 9-32.

Chakrabarty, Dipesh 2008, Provincializing Europe: Postcolonial Thought and Historical Difference, Second Edition, Princeton, NJ.: Princeton University Press.

Chatterjee, Partha 1983, 'Peasants, Politics and Historiography: A Response', Social Scientist, 11, 5: 64-5.

Chatterjee, Partha 1993, The Nation and Its Fragments: Colonial and Postcolonial Histories, Princeton, NJ.: Princeton University Press. Chatterjee, Partha 2010, 'A Brief History of Subaltern Studies', in Empire and Nation: Selected Essays, New York: Columbia University Press.

Chatterjee, Partha 2013, 'Subaltern Studies and Capital', Economic \& Political Weekly, 48, 37: 69-75.

Chattopadhyaya, Utathya 2014, 'Time to Move On? A Response to Vivek Chibber', Kritik, Unit for Criticism and Interpretive Theory, University of Illinois, available at: <https://unitforcriticism.wordpress.com/2014/06/26/authorsroundtable-vivek-chibber-postcolonial-theory-and-the-specter-ofcapital-response-by-utathya-chattopadhyaya/>.

Chibber, Vivek 2011, 'What Is Living and What Is Dead in the Marxist Theory of History?', Historical Materialism, 19, 2: 60-91.

Chibber, Vivek 2013, Postcolonial Theory and the Specter of Capital, London: Verso.

Chibber, Vivek 2014a, 'Revisiting Subaltern Studies', Economic \& Political Weekly, 49, 9: 82-5. 
Chibber, Vivek 2014b, 'Making Sense of Postcolonial Theory: A Response to Gayatri Chakravorty Spivak', Cambridge Review of International Affairs, 27, 3: 617-24.

Cooper, Frederick 2005, Colonialism in Question: Theory, Knowledge, History, Berkeley: University of California Press.

Coronil, Fernando 1996, 'Beyond Occidentalism: Toward Nonimperial Geohistorical Categories', Cultural Anthropology, 11, 1: 51-87.

Davidson, Neil 2012, How Revolutionary Were the Bourgeois Revolutions?, Chicago: Haymarket Books.

Delphy, Christine and Diana Leonard 1984, Close to Home: A Materialist Analysis of Women's Oppression, translated and edited by Diana Leonard, London: Hutchinson in association with the Explorations in Feminism Collective.

Dirlik, Arif 1997, The Postcolonial Aura: Third World Criticism in the Age of Global Capitalism, Oxford: Westview Press.

Fanon, Frantz 1963, The Wretched of the Earth, translated by Constance Farrington, New York: Grove Press.

Federici, Silvia 2012, Revolution at Point Zero: Housework, Reproduction, and Feminist Struggle, Oakland, CA.: PM Press.

Goswami, Manu 2004, Producing India: From Colonial Economy to National Space, Chicago: University of Chicago Press.

Guha, Ranajit 1982, 'On Some Aspects of the Historiography of Colonial India', Subaltern Studies, 1: 1-8.

Guha, Ranajit 1997, Dominance without Hegemony: History and Power in Colonial India, Cambridge, MA.: Harvard University Press.

Halperin, Sandra 2006, 'International Relations Theory and the Hegemony of Western Conceptions of Modernity', in Decolonizing International Relations, edited by Branwen Gruffydd Jones, Lanham, MD.: Rowman and Littlefield.

Inayatullah, Naeem and David L. Blaney 2004, International Relations and the Problem of Difference, New York: Routledge.

Jani, Pranav 2014, 'Marxism and the Future of Postcolonial Theory', International Socialist Review, 92, 2, available at: $<$ https://isreview.org/issue/92/marxism-and-future-postcolonialtheory-0>.

Journal of World-Systems Research 2014, Book Review Symposium on Postcolonial Theory and the Specter of Capital by Vivek Chibber, edited by Ho-fung Hung, Volume 20, Issue 2, pp. 281317. 
Kaiwar, Vasant 2004, 'Towards Orientalism and Nativism: The Impasse of Subaltern Studies. Review of Provincializing Europe: Postcolonial Thought and Historical Difference by Dipesh Chakrabarty and Dominance without Hegemony: History and Power in Colonial India by Ranajit Guha', Historical Materialism, 12, 2: 189-247.

Kaiwar, Vasant 2014, The Postcolonial Orient: The Politics of Difference and the Project of Provincialising Europe, Historical Materialism Book Series, Leiden: Brill.

Larsen, Neil 2001, Determinations: Essays on Theory, Narrative and Nation in the Americas, London: Verso.

Lazarus, Neil 2002, 'The Fetish of "The West" in Postcolonial Theory', in Marxism, Modernity and Postcolonial Studies, edited by Crystal Bartolovich and Neil Lazarus, Cambridge: Cambridge University Press.

Lazarus, Neil 2011, The Postcolonial Unconscious, Cambridge: Cambridge University Press.

Lazarus, Neil 2016, 'Vivek Chibber and the Specter of Postcolonial Theory', Race \& Class, 57, 3: 88-106.

Lazarus, Neil and Rashmi Varma 2008, 'Marxism and Postcolonial Studies', in Critical Companion to Contemporary Marxism, edited by Jacques Bidet and Stathis Kouvelakis, Historical Materialism Book Series, Leiden: Brill.

Levien, Michael 2013, 'Subalternists Scrutinized. Review of Postcolonial Theory and the Specter of Capital by Vivek Chibber', European Journal of Sociology, 54, 3: 485-97.

Löwy, Michael 1981, The Politics of Combined and Uneven Development: The Theory of Permanent Revolution, London: Verso.

Marx, Karl 1973, Grundrisse: Foundations of the Critique of Political Economy, translated by Martin Nicolaus, Harmondsworth: Penguin.

Matin, Kamran 2013, 'Redeeming the Universal: Postcolonialism and the Inner Life of Eurocentrism', European Journal of International Relations, 19, 2: 353-77.

Mills, Charles W. 1997, The Racial Contract, Ithaca, NY.: Cornell University Press.

Murphet, Julian 2014, 'No Alternative', The Cambridge Journal of Postcolonial Literary Inquiry, 1, 1: 157-63.

Nilsen, Alf Gunvald 2015, 'Passages from Marxism to Postcolonialism: A Comment on Vivek Chibber's Postcolonial Theory and the Specter of Capital', Critical Sociology, OnlineFirst, <https://doi.org/10.1177/0896920515614982>. 
Parry, Benita 2004, Postcolonial Studies: A Materialist Critique. London: Routledge.

Parry, Benita 2017,'The Constraints of Chibber's Criticism', Historical Materialism, 25, 1: 185-206.

Rosenberg, Justin 2006, 'Why Is There No International Historical Sociology?', European Journal of International Relations, 12, 3: 307-40.

Rosenberg, Justin 2013, 'The Philosophical Premises of Uneven and Combined Development', Review of International Studies, 39, 3: 569-97.

Roy, Ananya 2015, 'Who Is Afraid of Postcolonial Theory?', International Journal of Urban and Regional Research, OnlineFirst, <http://dx.doi.org/10.1111/1468-2427.12274>.

Said, Edward 1978, Orientalism: Western Conceptions of the Orient, London: Routledge and Kegan Paul.

Schwartz, Michael 2014, 'Capitalist Development, Structural Constraint and Human Agency in the Global South', Journal of World-Systems Research, 20, 2: 294-9.

Seth, Sanjay 2014, Review of Postcolonial Theory and the Spectre of Capital by Vivek Chibber, American Historical Review, 119, 4: 1218-20.

Shilliam, Robbie 2009, 'The Atlantic as a Vector of Uneven and Combined Development', Cambridge Review of International Affairs, 22, 1: 69-88.

Spivak, Gayatri Chakravorty 2014, 'Postcolonial Theory and the Specter of Capital', Cambridge Review of International Affairs, 27, 1: 184-98.

Taylor, Marcus 2010, 'Histories of World Capitalism, Methodologies of World Labour: Rethinking Uneven Development', paper presented at the ECPR Standing Group on International Relations, Stockholm, 15 July.

Tenbruck, Friedrich 1994, 'Internal History of Society or Universal History', Theory, Culture \& Society, 11: 75-93.

Trotsky, Leon D. 1962 [1931/1906], The Permanent Revolution and Results \& Prospects, London: New Park Publications.

Trotsky, Leon D. 1969 [1907], 1905, Paris: Les Éditions de Minuit.

Trotsky, Leon D. 1972 [1933], 'Uneven and Combined Development and the Role of American Imperialism: Minutes of a Discussion', in Writings of Leon Trotsky, 1932-33, edited by George Breitman and Sarah Lovell, New York: Pathfinder. 
Trotsky, Leon D. 2008 [1930-2], The History of the Russian Revolution, translated by Max Eastman, Chicago: Haymarket Books.

Vanaik, Achin 2013, 'Powerful Critique of Postcolonial Theory', Economic \& Political Weekly, 48, 28: 27-31.

Washbrook, David 1990, 'South Asia, the World System, and World Capitalism', The Journal of Asian Studies, 49, 3: 479-82.

Watson, Matthew C. 2013, 'The Poverty of Postcolonial Theory?', Postcolonial Studies, 16, 2: 230-2.

Young, Robert J.C. 2001, Postcolonialism: An Historical Introduction, Oxford: Blackwell. 